\title{
Ambiguity of the Word 'Road' in Russian Folklore Language
}

\author{
Elena Mikitchenko \\ Department of Russian Language \\ Sanya University \\ Sanya, China \\ E-mail: homeuniversity@mail.ru
}

\begin{abstract}
This paper considers the ambiguity of meanings of the word 'road' in Russian folklore, studies the principle of interchangeable relationship in folklore language, based on the similarity of the concepts rather than of the meanings. Through the phenomena of the paradigm of accuracy, synonymous approximation and quasi synonymy the existence of the correlative emphatic constructions type, such as 'pathway', 'swan-geese', 'friends-comrades' and other, is explained. This demonstrates that the laconic brevity of folklore language and its apparent simplicity underneath are like a transparent water depth where even one word is capable of transferring 'the abyss of space' of thought and feeling of the immense complex psychic processes into a harmonious unity with the beauty of the folklore world.
\end{abstract}

Keywords-path-way; folklore language; synonymous approximation; quasi synonymy; ambiguity; diffuziness of meanings

\section{INTRODUCTION}

The Russian language has some expressions consisting of two words, as if fused together, that semantically reinforce each other-друзья-товарищи (lit. friends-comrades), nуть-дорога (lit. path-way), грусть-тоска (lit. blues and blahs), конца-краю нет (lit. one can see no end to it), гусилебеди (lit. swan-geese), скок-поскок (lit. thuтрity thuтр), суженьй-ряженый (lit. betrothed), чудо-чудное (lit. wonderworks), диво-дивное (lit. wonder of wonders), жилибыли (lit. опсе ироп а time), жить-поживать (lit. to live happily ever after), etc. All they have preserved their active use down the ages in so much as folklore is their source. Few of them are understood as synonyms, some as tautological repeats, others raise questions since they cannot be assigned to the synonymy category in modern-day Russian (суженый-ряженый (lit. betrothed), щекотуха-лепетуха (lit. itchem-telltale), гуси-лебеди (lit. swan-geese), майорполковничек (lit. major-colonel)). Those expressions could be considered as original comparisons-geese beautiful like swan; the major is so portly and important-looking just like the colonel. However, not all such expressions can fit into such explanations-суженый (betrothed) means somebody who becomes one's fate, ряженьй - means the marriage has already been agreed upon, arranged; to tickle-babble (щекотуха-лепетуха) - those words standing in pair are neither the common language synonyms nor common figures of speech.

Prominent scholars A. T. Khrolenko, L. G. Nevskaya and S. E. Nikitina dedicated their works to such folklore paired expressions (дунай-дорожка (lit. danube-path), гусилебеди (geese-swan) and other). To understand the phenomenon's contents, they were pointing to the need to address the peculiarities of folklore language and the originality of the folk worldview. A. N. Afanasyev calls the body of denotations, ties and relationship in the linguistic worldview of folklore the ground, nourishing "the seed of pristine word" [1].

A.T. Khrolenko in his work The Semantics of Folklore World writes "The description of the folklore language's lexicographic aspect should go in two main and interrelated ways: the registration of its inventory (words and configurations) - the external aspect - and the investigation of the folk word specificity in its system bond with other words in text - the internal aspect [2].

As long as the folklore text presents, in fact, a figurative piece of art, while studying the folk word semantics, it is important to consider not only the semantics of non-poetic language but the poetic context, to which it belongs, and the traditions of the preceding poetic language of this genre.

It is important to realize when addressing the words path and road as the key words of the folklore text (especially of some genres: epic poems, fairy tales, lamentations, charms) that they carry additional semantics, defined by structural attributes of the folklore worldview, along with this each genre opens own side of this ideal atemporal being.

\section{SYNONYMS TO THE WORD 'ROAD' IN FOLKLORE TEXTS}

\section{A. Common Language Synonyms}

The first (material) meaning of the word road is central and has the following synonyms:

- $a$ way, and the word way can be of feminine gender for example: "The way, to you, road (дороженька, 
feminine), is set through a new trail, green grass, icy water",

- crossroads: "Was emptying water out of a bowl onto crossroads (road)",2 [3].

The Russian word росстань (lit. crossroads) often is used when it is referred to three roads: "From the stone three roads, three roads, three pathways, three pathways directional"3; "I'm going to the fields, in the fields there're three roads" . But this can also be referred to two roads: "I'm going to the fields. There are - two pathways, two roads there" [4] [5] [6].

In the Explanatory Dictionary by Vladimir Dal, in the article "Разставлять" (lit. to set, arrange) we meet the interpretation of the words разстанки, розстани, роставни. The word розстани is explained through the synonyms carrefour, crossway, crossroads where those, who are taking the road to, are accompanied, where people separate, part ways, for example: "At the crossroads in front of the small chapel we'll pray and start our way, with God's help!" [7].

Crossing roads are called crossroads, intersection "where some way transverses another" and "roads diverge crosswise" [8].

There is also the expression развилина дорожная (lit. $a$ road (rotch). The road crotch can be made by a bifurcating road, otherwise - "by parting of the ways, fork, crossroads where a road diverges in two and more" [9].

\section{B. Synonymic Affinity and Quasi Synonyms}

It must be remembered that to the greater extent folklore reflects the model of oral speech, its generalized properties. Naming of one and the same culture-specific concept by different yet thematically-sensitive words is typical for folklore texts, for example:

- "Your way, path, is arranged by a new track, green grass, shivering water",

- "Down a wide good street,

Down a beaten path

Was riding out a major-colonel" ${ }^{8}[10]$.

\footnotetext{
"Путь, тебе, дороженька, налажена новой тропой, зеленой травой, студеной водой”.

“Воду из таза выливала на росстань (дорогу)".

“От камешка три росстани, три росстани, три дороженьки, три дороженьки путистые”

4 “Выйду в чисто поле, в чистом поле три росстани".

“Выйду я в чисто поле. Там - две дороги, там две росстани».

"На розстанях перед часовенкой помолимся, а и с Богом в путь!”

"Путь тебе, дороженька, налажена новой тропой, зеленой травой, студеной водой”

8 "По широкой было славной улице,

9 По проезжей-то было по дорожечке

10 Выезжал-то майор да полковничек”.
}

As a road runs along a street, and the street co-opts a roadway, a road itself, the words street and road are employed here as quasi synonyms.

It is to be noted that the understanding of common language synonyms differs from the understanding of synonyms in folklore, since here one should consider the uniqueness of the folk-linguistic worldview, the synonymy in which rests on the similarity of representations, rather than on the similarity of definitions.

In the folk-poetic speech there are two types of synonyms:

- Synonymic affinity realized in linear syntagmatic relations and acting as circumstantiation (for example, правда-истина (truth-verity), друзья-товарищи (friends-comrades); also, the expression nymbдорога (path-way), and

- Quasi synonyms, realized in non-linear paradigmatic relations and performing the substitution function, whereas virtually any words, which evoke the folklore tradition bearers' similar semantic associations, are able to substitute each other (apple pear, nightingale - pigeon, road - street).

A. T. Khrolenko calls the extremely expanded representativeness of a folk word 'paradigmaticalness' and associates it with the peculiarities of a folklore text, wherein "sorting of all possible forms of the paradigm is achieved through assertion. This contributes to a wide variation of syntactic units given an exceptional stability of artisticsemantic and stylistic constants" [11].

\section{Oppositions to the Word 'Road'}

Road in its central meaning is opposed to trace, somebody's tracks or impassable road, for example:

- In lamentations:

“There's no passage on trotting horses,

There's no passage in somber deep forests,

No coachman's road,

Only a small path..."9 [12].

- In spells:

"... shall not go the direct road - by mouse's holes and fox's trails" ${ }^{\prime 10}$ [13].

A straight road in this case, as an open honest way (method), is opposed to a sneak, secret, dark and evil way "cat's path", "mouse's trail”, “dog tracks":

"I'll stand, without blessing, shall go out without crossing, and not from doors to doors, and not from gates to

11 “Нет проезду на ступистых лошадушках, Нет проходу во темных лесах дремучих, Почтовой ямской нет дороженьки,

Только малая единая тропиночка...».

12 “... пойду не прямой дорогой - мышьими норами да лисьими тропами”. 
gates, by mouse's trail, basement log, cat's path, twisted garden...", "Shall follow mole-rat tracks", "by snake hole", "smoke window", "bottom way, basement log, mouse trails, dog tracks"11 [14];

- In spiritual poetry and lamentations:

"And went they (pilgrims) cross the open fields,

Not by road - by impassable land"12 [15].

In recruitment lamentations and songs, road is opposed to somber forests:

"And I ran, a good fellow, not by path-way, [16].

And I ran, a good fellow, through somber forests"13

\section{THE MEANING OF THE WORD ‘ROAD’ IN FOLKLORE TEXTS}

All the meanings of the word "road" in folklore works basically coincide with the data of modern explanatory dictionaries, but sometimes they seems to be beyond the common language meanings and include values absent in the contemporary standard Russian.

The central meaning of the word 'road':

1) 'a strip of land for dislocation and moving'

"A white birch stood roadside"14 [17].

"Blow, strong winds, cover the road with yellow sand Road, grow with little fir wood and birch grove..." ${ }^{\text {[18]. }}$

Beside the central meaning, the word 'road' carries many connotations:

2) 'track'

- as a paw print / prints

"... so the young bull would not linger, would not spring in a harrow, from the track where did not run, where the road is - thereon his leg is"16 [19];

- as some cover formed by friable particles

"Blossomed, blossomed the bird-cherry

In white leaves,

13 “Стану я, не благословясь, выйду я, не перекрестясь, и не из дверей в двери, и не из ворот в ворота, мышьей тропой, подвальным бревном, кошачьей дорогой, косой огородой...”, “пойду по кротиным следам”, “змеиной норою”, “дымным окном”, “нижним ходом, подвальным бревном, мышьими тропами, собачьими следами”.

14 “И пошли они (калики) по чисту полю, Не дорогою - бездорожицею".

15 “Что бежал-то я, добрый молодец, не путем-дорогой, А бежал я, добрый молодец, темными лесами”.

16 “Стояла белая березка у краю дороги”

17 “Задуйте, сильные ветры, занесите дорожку желтым песочком. Зарастай, дорога, мелким ельничком да березником...”,

18 “...так бы быченько не задерживался, в боронку не скакал, со следу куда не бежал, куда дорожка - туда ножка”

\section{Covered, covered the road}

In white leaves..." ${ }^{17}$ [20];

3) 'a place that one can get over'

"There're stump and chunk behind, tar and fire on each side, ahead - the way and path" ${ }^{, 18}$ [21];

4) 'place in a stove, the middle strip of hearthstone'

"Schekotukha-lepetukha! Play with the stone, behind the road, but don't play with my baby"19 (charming away the crying and insomnia) [22];

5) 'travelling on foot, a trip, a journey',

“... save and protect Christian (so-and-so), in wood and in the field, on my way, on the road - against steel, fire, a wild man"20 [23];

6) 'route'

"...to come back, didn't forget the way" ${ }^{21}$ (the spell against the loss of grazing cow) [24];

7) 'direction'

"Fire Martyn, here is your iron palisade, your way is from the earth to the sky, don't fire anywhere anymore" ${ }^{22}$ $[25]$

"All well springs and rafts run from all roads into this brook..." [26];

8) 'possibility of moving'

"I take a bee of the swarm and put into hive... You, the bee, swarm, Christian (so-and-so) ... Queen, I lock all ways and paths..."23 [27];

9) 'opportunity, access'

"I sweep, sweep away, clear the way to my destinedbetrothed" 24 [28];

10) 'good luck, a stroke of luck'

"Withersoever goes, rides, his path-way is everywhere. Walks through the wood - no tree wounds, walks through the fields - no beast harms, will go to court - the court

19 “Цвела, цвела черемуха

Белым листом,

Стлала, стлала дороженьку

Белым листом..."

20 “Сзади пень да колода, по бокам смола да огонь, вперед путь да дорога".

21 “Щекотуха-лепетуха! Тешься печью, за дорогой, а не тешься моим младенцем".

22 “... спаси и сохрани рабу божию (имя), меня в лесу и в поле, в $n у т и$, в дороге - от меча, от огня, от дикого человека".

23 “... чтоб обратно приходила, дорогу не забыла”.

24 “Огонь Мартын, вот тебе железный тын, от земли до неба дорога твоя, больше пламя не пускай никуда"

25 “Беру я пчелу роя и сажаю в улей...Ты, пчела, роися у меня, раба Божия (имя).... Замыкаю я тебе, матка, все пути-дороги...”

26 "Мету, разметаю, моему суженому-ряженому дорожку расчищаю" 
wouldn't judge, all judges will be pierced to the heart, the people will wonder" ${ }^{25}$ [29];

11) 'method'

"But the medicine man goes the beaten track and is afraid to stumble. He talks learnedly, smoothly"26 [30];

12) 'spiritual choice, a path of spiritual development'

"Your servant (so-and-so) goes the holly path".

"I'll go to the path of light. The Most Holy Mother stand up to help me"27 [31].

Less common meanings are:

13) 'a strand of hair breaking loose'

"To leave a strand of hair unbraided while brushing means the way from home" [32].

Let us compare one of the spells aimed to tame a purchased animal, "blocking the way" to the previous owner: "Shall spin in the road, eat grief, forget sadness" 28 [33]. Seems interesting the image of road as yarn (a strand of hair and 'shall spin in the road').

Image of the road as a cover, bed is well-known (in the modern use - 'railway bed'), which had translated into a certain magic action: "When someone's cow has been lost, a towel, which hands' are wiped on, was wound round the leg of a table standing in the icon corner and it was repeated three times "How soon the towel on the leg spins, so soon I shall find the cow"29 [34].

Such method was used when somebody was lost in the woods: They spanned a towel around a tree trunk and kept repeating, "How soon the towel on the pine tree spins, so soon shall find the way",30 [35].

The formal resemblance of a road and a cover let the towel assume the functions of a road. Therefore, it was necessary to 'properly' use the towel to find the way. In this regard, we can recall such expressions as держать nymb (to wend one's way) (literally, to hold in one's hands, control the 'roadbed') and скатертью дорога (good riddance) (namely, the way is open, free for passing).

A special attention should be paid to one more meaning of the word road in the folklore texts - the road as

14) 'a river, basin'

27 “Куда ни пойдет, ни поедет, все ему путь-дорога. Лесом идет - деревом не бьет, полем идет - зверь не тронет, в суд пойдет - суд судить не будет, у всех судьев сердца умиляться, весь народ удивится".

28 “Знахарь же идет торной дорогой и боится оступиться. Он говорит по-ученому, как по-писаному”.

29 “Раба твоя (имя) идет по святой дороге. Пойду на светлую дорогу. Мать Божия, встань мне на помощь”.

30 “Дорогу упряду, тоску съем, печаль забуду”.

31 “Сколь скоро полотенце на ножку навью, столь скоро и скотинку найду”.

32 “Сколь скоро полотенце на сосенку навью, столь скоро я дорожку найду”.
- "from that very danube the path runs, runs the danubepath wide, penetrating"31 [36].

A. T. Khrolenko considers as commonly held opinion that "Danube in Russian folklore is not just the toponym, but also the generic notion 'a body of water', compare dunaj (Old Polish) - a far unknown river, a sea; dunaj (Polish) black waters, дунай (Ukr.) - a puddle, water overflow; дунай (Rus.) - a brook (Olon., Kirovsk.)" [37].

Consequently, it is possible that in the above charm "All well springs and rafts run from all roads into this brook, hurry, find their way... ${ }^{, 32}$ the word road is supposedly used in the meaning of "a well spring, creek, runlet" rather than "a direction" [38].

D. N. Shmelyov introduces the concept of diffuzziness "an admissible alignment of some meanings of words, creating the effect of a word's notional capacity in this particular case, provided, however, a clear-cut parting of these meanings in other positions" [39].

For instance, people's view of the relation of the nationally biased units 'road' and 'street' is reflected in the song:

"A road ran here,

In width not wide,

In length - no end to it.

Along the road - a new street,

A new Moskovskaya street,

Moskovskaya, Posadskaya",33 [40].

where meaning of the words street and road is sharply delineated.

D. N. Shmelyov distinguishes two types of the diffuziness: external, expanding beyond the word (path-way), and internal - inside a multivalent word, when meanings, differing in one contexts, act inseparably in other. Such indefiniteness can be applicable to all meanings of a word and is attributed, according to S. E. Nikitina, to the availability of the so-called central meaning of the word or to the depth notation, uniting meanings of another level [41].

\section{CONCLUSION}

The apparent simplicity of language, based on a certain limited vocabulary, presents the defining feature of folklore

\footnotetext{
33 “...от того ли от дунаю пролегла дорожка, пролегла дунай дорожка широка, пробориста"

34 “В этот ручей бежат все ключи и заторы со всех дорог, торопятся, сноровятся...”.

35 “Пролегала тут дороженька, Шириной она не широкая,

А длиною - конца-края нет.

36 По дорожиньки - нова улица

37 Нова улица Московская,

38 Московская, Посадская"
} 
works, as many scholars note (V. V. Vinogradov, M. M. Prishvin, A. A. Gorelov, etc.).

To paraphrase Nikolai Gogol, it should be emphasized that word's laconic brevity bases on the beauty of the folk word with its fabulous "fathomless space" of thought and feeling, that this transparent depth of the language is taken for its simplicity and implies the aspiration to bring the most complex mental processes to a harmonious unity, while the quantitative limitation of the lexical items' stock is compensated by the paradigmaticalness, the diffuziness of meanings, the increased valency and the polysemy of the folk word [42].

\section{REFERENCES}

[1] N. Afanasyev, Poetic beliefs of the Slavs on nature, M.: 1865-1889, (1994 Reprint), p. 15.

[2] A. T. Khrolenko, Semantics of folklore word. Voronezh, Voronezh University Press, 1992,p.8.

[3] Peasant lyrics, Under the general editorship of M. Azadovsky, L.: Soviet Writer, 1935, p. 67.

[4] A. T. Khrolenko, pp. 26, 37.

[5] D. N. Shmelyov, The problems of semantic analysis of the vocabulary. M.: Nauka, 1973, p. 77.

[6] A. T. Khrolenko, p. 76.

[7] S. E. Nikitina, About polysemy, diffusion of meanings and synonymy in the thesaurus of folklore language. Word image. Collection of articles. M.: V. V. Vinogradov Russian Language Institute of the RAS, 1997, p. 363.

[8] Russian magic spells and sorcery. Materials of folklore expeditions in 1953-1993. Ed. V. P. Anikin, M.: MGU Press, 1998, 480 p., No. 349.

[9] Ibid., No. 981.

[10] Ibid., No. 1141.

[11] Russian folklore in Latvia: songs, cult and children's folklore. By I.D. Frederic, Riga, Liesma, 1972, 485 p.

[12] Russian magic spells and sorcery., No, 971.

[13] Ibid., No. 91.

[14] Ibid., No. 1013.

[15] Ibid., No. 1099.

[16] Ibid., No. 873.

[17] Ibid., No. 1142.

[18] Ibid., No. 1367.

[19] Ibid., No. 738.

[20] Ibid., No. 2412.

[21] Complete encyclopedia of Russian people's life by Ivan Pankeev, M., Olma-Press, 1998, Vol. 2, p. 90.

[22] Russian magic spells and sorcery., No. 406, No. 2407.

[23] Complete encyclopedia of Russian people's life by Ivan Pankeev, p.12.

[24] Russian magic spells and sorcery., No. 45.

[25] Ibid., No. 370.

[26] Ibid.

[27] A. T. Khrolenko, p. 32.

[28] Ibid.

[29] Russian magic spells and sorcery., No. 755.

[30] Ibid., No. 1141.

[31] Ibid., No. 145.

[32] Songs collected by Rybnikov. Petrozavodsk, Karelia Publishers, 1990, Vol.2, p. 131

[33] Russian magic spells and sorcery., No. 632.
[34] Ibid., No. 1438

[35] V. I. Dal, The Explanatory Dictionary of the Living Great Russian Language, M.: Russian Language, 1991, 1181 p., Vol. 4, p. 43.

[36] Ibid., Vol. 3, pp. 78, 61.

[37] Ibid., Vol. 4, pp. 1181.

[38] Northern Territory Lamentations, collected by E. V. Barsov, M.: 1874, Part 1, p. 142.

[39] Russian magic spells and sorcery., No. 165.

[40] Ibid., No.860-872.

[41] V. Varentsov, Book of Russian folk poems, SPb.: D. E. Kozhanchikov Publishing House, 1860, p. 142.

[42] The Peasant lyrics, p. 105.

[43] N. V. Gogol, A word on Pushkin. Collected works in seven volumes, M.: Khudozhestvennaya Literatura Publishers, 1978, V. 6, p. 68. 